\title{
Biocompatible Conjugated Fluorenylporphyrins for Two- photon Photodynamic Therapy and Fluorescence Imaging
}

\author{
Limiao Shi, ${ }^{\text {a }}$ Christophe Nguyen, ${ }^{\mathrm{b}}$ Morgane Daurat, ${ }^{\mathrm{b}, \mathrm{d}}$ Abdelhamid Chiheb Dhieb, ${ }^{\mathrm{a}, \mathrm{e}}$ Wajda \\ Smirani, ${ }^{\mathrm{e}}$ Mireille Blanchard-Desce, ${ }^{\mathrm{c}}$ Magali Gary-Bobo, ${ }^{\mathrm{b}}, *$ Olivier Mongin, ${ }^{\mathrm{a}, *}$ \\ Christine Paul-Roth, ${ }^{\mathrm{a}, *}$, Frédéric Paul ${ }^{\mathrm{a}}$
}

\begin{abstract}
${ }^{a}$ Univ Rennes, INSA Rennes, CNRS, ISCR (Institut des Sciences Chimiques de Rennes) UMR 6226, F-35000 Rennes, France. E-mail: christine.paul@insa-rennes.fr, olivier.mongin@univ-rennes1.fr

${ }^{b}$ Institut des Biomolécules Max Mousseron, UMR CNRS-UM-ENSCM 5247, UFR des Sciences Pharmaceutiques et Biologiques, 15 Avenue Charles Flahault, 34093 Montpellier Cedex 5, France. E-mail: magali.gary-bobo@inserm.fr

${ }^{c}$ Univ. Bordeaux, Institut des Sciences Moléculaires (CNRS UMR 5255), 33405 Talence, France.

${ }^{d}$ NanoMedSyn, 15 Avenue Charles Flahault, 34093 Montpellier Cedex 5, France.

${ }^{e}$ Laboratoire de Chimie des Matériaux, Faculté des Sciences de Bizerte, Université de Carthage, 7021 Zarzouna, Tunisia.
\end{abstract}

$\dagger \quad$ Electronic Supplementary Information (ESI) available: Full experimental and spectroscopic data. See DOI: 10.1039/b000000x/

The photophysical properties of a new series of fluorenyl porphyrins bearing watersolubilising oligoethyleneglycol chains are described. These biocompatible compounds present very good two-photon absorption and singlet oxygen generation properties, while retaining some fluorescence in water. After testing in vitro on breast cancer cells, some of them were shown to be efficient non-toxic two-photon photosensitisers allowing for fluorescence imaging, thus demonstrating their theranostic potential.

Photodynamic therapy (PDT) is an emerging technique for the treatment of cancers and other diseases, such as age-related macular degeneration (ARMD) or bacterial infections requiring the use of an efficient oxygen photosensitiser (PS). ${ }^{1}$ The activation of such PSs by two-photon 
excitation rather by one-photon excitation offers several advantages over classical PDT, including an increased penetration depth of the excitation beam in tissues thanks to the use of near infrared (NIR) wavelengths and an intrinsic three-dimensional resolution allowing for better spatial control of the ${ }^{1} \mathrm{O}_{2}$ generation. ${ }^{2}$ However, to achieve efficient treatments, the PSs have to be specifically designed for two-photon excitation ${ }^{3}$ and have to fulfill different requirements such as very large two-photon absorption (2PA) cross-sections in the biological window (700-1000 nm) and high singlet oxygen production quantum yields for oxygen sensitisation. ${ }^{4}$ Furthermore, if the PS is fluorescent, two-photon fluorescence monitoring can additionally be performed, leading to theranostic applications. ${ }^{3,5}$

Current clinical and preclinical photosensitisers are mostly porphyrin derivatives, which exhibit too low 2PA cross-sections in the NIR range (10 GM for Photofrin and $50 \mathrm{GM}$ for Visudyne) to be of any use for two-photon PDT (2P-PDT). ${ }^{6}$ While strong enhancements of the 2PA cross-sections can be achieved with extended $\pi$-delocalised systems, such as conjugated porphyrin dimers and oligomers, fused porphyrin arrays or expanded porphyrins, ${ }^{7}$ this large increase in the $2 \mathrm{PA}$ response is often obtained at the expense of other key photophysical properties (luminescence quantum yield, absence of overlap with any onephoton absorption in the NIR), which results in the loss of the intrinsic advantages of 2P-PDT over 1P-PDT, notably the 3D spatial selectivity of the therapy. To enhance intrinsic 2PA while retaining (or improving) the photosensitisation and fluorescence properties of isolated porphyrins, non-conjugated assemblies based on FRET from donor two-photon absorbers to acceptor porphyrin photosensitisers have been developed. ${ }^{8}$ A related approach has been focused on "semi-disconnected" systems in which a weak conjugation between two-photon absorbing (linear or dendritic) peripheral antennae and a central porphyrin core is maintained. ${ }^{9}$ In such systems, the different parts of the PS do not behave fully independently, but maintain some electronic interaction, allowing to speed up the intramolecular energy transfer between them, i.e. between the peripheral 2PA-antennae and the porphyrin core at the origin of the oxygen photosensitisation. In such molecular assemblies, enhancement of the 2PA efficiency of the peripheral branches does only marginally affect the key photophysical properties of the central core.

For such an approach, we have tested several star-shaped porphyrins, among which 1a and 2a were our best candidates for 2P-PDT based on the photophysical properties in organic solvents (Scheme 1). Thus, they present intrinsic 2PA cross-sections of 380 and $770 \mathrm{GM}$, respectively, and comparable or better fluorescence and photosensitisation properties than tetraphenylporphyrin $\left(\mathrm{H}_{2} \mathrm{TPP}\right){ }^{9 \mathrm{~d},}{ }^{9 \mathrm{e}}$ In this communication, we now want to report the performances of their biocompatible analogues (1) and $\mathbf{2 b - c}$ ) featuring hydrophilic triethyleneglycol (TEG) chains in place of some of the butyl chains of 1a and $\mathbf{2 a}$. 


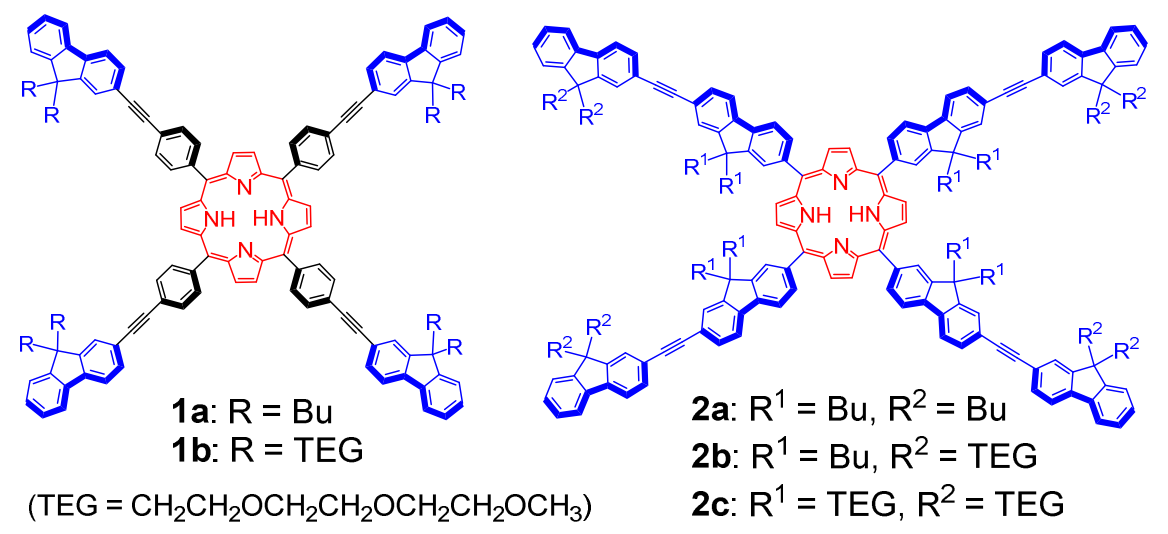

Scheme 1 Selected meso-tetraarylporphyrin-based semi-disconnected PSs.

The synthesis of the reference compounds 1-2a has been described previously, ${ }^{9 \mathrm{~d}, 9 \mathrm{e}}$ whereas that of the new compounds $\mathbf{1 b}$ and $\mathbf{2 b - c}$ will be detailed elsewhere (see ESI for their characterisation). Briefly, these PSs were obtained similarly to 1-2a in a multistep sequence using fluorene synthons functionalised with TEG chains. The absorption spectra of these fluorenyl porphyrins display typical characteristics of tetraarylporphyrins (Table 1), such as an intense Soret band near $430 \mathrm{~nm}$ and four Q-bands in the 515-655 nm range, along with a strong structured band in the UV range (300-400 nm), corresponding to the absorption of the conjugated arms (Table 1 and Fig. 1). Their emission spectra are also diagnostic of porphyrin emission with two $\mathrm{Q}(0,0)$ and $\mathrm{Q}(0,1)$ peaks. Their excitation spectra closely resemble the corresponding absorption spectra (ESI, Fig. S1). Notably, likewise to 1-2a, the new compounds $\mathbf{1 b}$ and $\mathbf{2 b - c}$ also exhibit quantum yields for singlet oxygen generation similar to that of $\mathrm{H}_{2}$ TPP, showing that the increase of their fluorescence efficiency (in comparison with $\mathrm{H}_{2}$ TPP) is not obtained at the expense of the singlet oxygen production. The replacement of butyl chains with TEG chains on the fluorenyl units has therefore a very limited influence on their linear optical properties in organic media of low polarities. Absorption and emission spectra of $\mathbf{1 b}$ and $\mathbf{2 b - c}$ were also recorded in water (ESI, Fig. S2 and Table S1) and these compounds were thus shown to retain some fluorescence, even if their quantum yields are clearly lower than in THF (3\% instead of $20-22 \%$ ). 


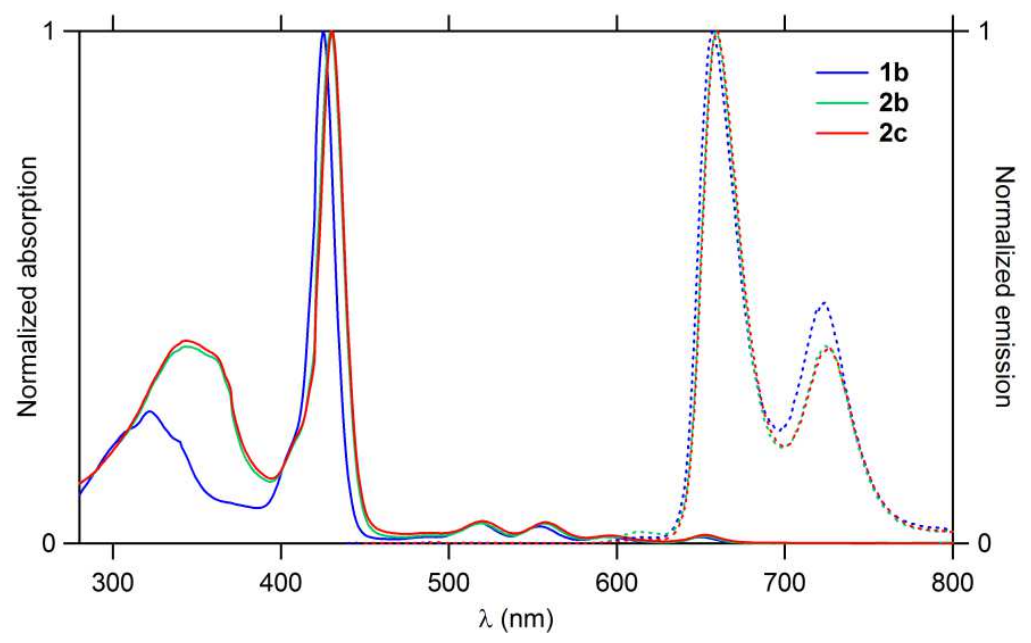

Fig. 1 Normalised absorption and emission spectra of $\mathbf{1 b}, \mathbf{2 b}$ and $\mathbf{2 c}$ in THF.

Two-photon absorption (2PA) measurements in the NIR were then conducted by two-photon excited fluorescence (2PEF) measurements in THF in the femtosecond regime (Table 1 and ESI, Fig. S3). A fully quadratic dependence of the fluorescence intensity on the excitation power was observed for each sample at all the wavelengths probed in the 790-920 nm range, indicating that the cross-sections so determined are due only to 2PA (ESI, Fig. S4-S6). The $2 \mathrm{PEF}$ emission spectra are diagnostic of porphyrin emission and closely resemble the corresponding 1PEF emission spectra (ESI, Fig. S7-S9). The 2PA cross-sections are significantly larger than that of $\mathrm{H}_{2} \mathrm{TPP}(12 \mathrm{GM}$ at $790 \mathrm{~nm}$ ), especially for porphyrins $\mathbf{2 b - c}$ which feature extended arms (810-820 GM at $790 \mathrm{~nm}$; Table 1). Again, comparison of the 2PA cross-section values found for $\mathbf{1 b}$ and $\mathbf{2 b - c}$ with those of their analogues 1-2a reveals that replacement of the butyl chains with TEG chains has almost no influence on the 2PA properties.

Table 1 Photophysical properties of porphyrins 1a-b and 2a-c.

\begin{tabular}{|c|c|c|c|c|c|c|c|c|c|c|c|c|c|}
\hline \multirow{2}{*}{ Cpnd } & \multicolumn{3}{|c|}{$\lambda_{\mathrm{abs}}^{\max }(\mathrm{nm})$} & \multirow{2}{*}{$\begin{array}{c}\varepsilon_{\text {Soret }} \\
\left(\mathrm{M}^{-1} \mathrm{~cm}^{-1}\right)\end{array}$} & \multirow{2}{*}{$\begin{array}{c}\lambda_{\mathrm{em}} \\
(\mathrm{nm})\end{array}$} & \multirow{2}{*}{$\Phi_{\mathrm{F}}{ }^{d}$} & \multirow{2}{*}{$\begin{array}{c}\tau \\
(\mathrm{ns})\end{array}$} & \multirow{2}{*}{$\Phi_{\mathrm{F}}{ }^{e}$} & \multirow{2}{*}{$\Phi_{\Delta}^{f}$} & \multirow{2}{*}{$\begin{array}{c}\sigma_{2}^{\max } \\
(\mathrm{GM})^{g}\end{array}$} & \multirow{2}{*}{$\begin{array}{c}\Phi_{\mathrm{F}} \sigma_{2} \\
(\mathrm{GM})\end{array}$} & \multirow{2}{*}{$\begin{array}{l}\Phi_{\Delta} \sigma_{2} \\
(\mathrm{GM})\end{array}$} & \multirow{2}{*}{$\begin{array}{l}\text { Enhancement } \\
\text { factor }^{i}\end{array}$} \\
\hline & UV band & Soret & Q-bands & & & & & & & & & & \\
\hline $\mathrm{H}_{2} \mathrm{TPP}^{a}$ & 1 & 420 & $514,548,590,649$ & 440000 & 652,719 & 0.11 & 9.9 & - & 0.60 & $12^{h}$ & 1.3 & 7.2 & 1 \\
\hline $1 \mathbf{a}^{b}$ & 324 & 426 & $518,555,592,650$ & 670000 & 657,722 & 0.20 & 8.3 & - & 0.70 & 380 & 76 & 266 & 37 \\
\hline $1 b^{c}$ & 322 & 425 & $518,554,595,650$ & 617000 & 657,722 & 0.20 & 9.9 & 0.03 & 0.60 & 340 & 68 & 204 & 28 \\
\hline $2 \mathbf{a}^{b}$ & 339 & 432 & $520,557,598,652$ & 669000 & 660,726 & 0.23 & 8.0 & - & 0.62 & 770 & 177 & 477 & 66 \\
\hline $2 \mathbf{b}^{c}$ & 343 & 430 & $520,557,596,652$ & 607000 & 659,724 & 0.21 & 9.7 & 0.03 & 0.59 & 810 & 170 & 478 & 66 \\
\hline $2 c^{c}$ & 343 & 430 & $520,558,596,653$ & 583000 & 660,727 & 0.22 & 9.8 & 0.03 & 0.58 & 820 & 180 & 476 & 66 \\
\hline
\end{tabular}

${ }^{a}$ Data from lit. ${ }^{9 \mathrm{~d}, 9 \mathrm{e} b}$ Data in dichloromethane, fom lit. ${ }^{9 \mathrm{~d}, 9 \mathrm{ec}}$ Data in THF (this work). ${ }^{d}$ Fluorescence quantum yield, using $\mathrm{H}_{2} \mathrm{TPP}$ in toluene $\left(\Phi_{\mathrm{F}}=0.11\right)$ as standard, upon excitation at Soret band. ${ }^{e}$ Fluorescence quantum yield in water. ${ }^{f}$ Singlet oxygen production quantum yield in dichloromethane, determined relative to $\mathrm{H}_{2} \mathrm{TPP}$ in dichloromethane $\left(\Phi_{\Delta}\left[\mathrm{H}_{2} \mathrm{TPP}\right]=0.60\right) .{ }^{g}$ Intrinsic $2 \mathrm{PA}$ cross-sections at $790 \mathrm{~nm}\left(10^{-4} \mathrm{M}\right.$ solutions $)$ measured by $2 \mathrm{PEF} .{ }^{h}$ Data from lit. ${ }^{10 i}$ Two-photon excited oxygen sensitisation enhancement factor: $\Phi_{\Delta} \sigma_{2}$ of the compound normalised to that of $\mathrm{H}_{2} \mathrm{TPP}$. 
Along with their solubility in water, their large singlet oxygen quantum yields $\left(\Phi_{\Delta}\right)$ and large 2PA cross-sections $\left(\sigma_{2}\right)$ make $\mathbf{1 b}$ and $\mathbf{2 b}$-c promising candidates for achieving 2P-PDT, since they present high $\Phi_{\Delta} \sigma_{2}$ values, a figure of merit commonly used for evaluating two-photon excited oxygen sensitisation properties of PSs. To check that point, their theranostic potential (diagnosis and cancer therapy) was investigated on human breast cancer cells (MCF-7) under two-photon excitation. At first, their biocompatibility was evaluated in vitro. For this, MCF-7 cells were incubated for $72 \mathrm{~h}$ in the darkness, with increasing concentrations of each porphyrin (from 0.1 to $200 \mu \mathrm{g} \mathrm{mL}^{-1}$ ). Results demonstrated no cytotoxicity up to $50 \mu \mathrm{g} \mathrm{mL}^{-1}$ (ESI, Fig. S10). Compound $\mathbf{2 b}$ was the less cytotoxic of these compounds in the absence of light excitation ( $30 \%$ of cell death at $200 \mu \mathrm{g} \mathrm{mL}^{-1}$ ).

The efficiency of these compounds in two-photon excited photodynamic therapy (2P-PDT) was next studied. MCF-7 cells were thus incubated for $24 \mathrm{~h}$ with porphyrins at a concentration of $25 \mu \mathrm{g} \mathrm{mL} \mathrm{m}^{-1}$ and subsequently irradiated with a pulsed laser (Fig. 2). Irradiation was performed at $790 \mathrm{~nm}$ by 3 scans of $1.57 \mathrm{sec}$ each one, with a focused laser beam (LSM 780, Chameleon) at the maximum laser power. Whereas these compounds exhibit no significant cytotoxicity without irradiation, after irradiation of less than 5 seconds $(3 \times$ $1.57 \mathrm{sec})$, the cell death quantification assay performed 2 days after irradiation clearly demonstrates a decrease in living cells with all compounds. The strongest effect was observed for $\mathbf{2 b}$ with $72 \%$ of cell death. Porphyrin $\mathbf{2 b}$ exhibits thus a higher efficacy than $\mathbf{1 b}$ ( $40 \%$ cell death), in line with its higher $\Phi_{\Delta} \sigma_{2}$ figure of merit at $790 \mathrm{~nm}$. However, other parameters have also to be considered to rationalise this observation, as $\mathbf{2 c}$, which exhibits exactly the same $\Phi_{\Delta} \sigma_{2}$ value than $\mathbf{2 b}$, has a much lower 2P-PDT efficacy (25\% cell death). Porphyrins $\mathbf{2 b}$ and 2c have exactly the same overall structure and differ only by the substituents $\mathrm{R}^{1}$ on the "inner" fluorenes. Thus, the strong effect stated on the biological properties, induced by an apparently small structural difference, might be related to other parameters than purely photophysical ones. Modifications of the hydrophilicity-hydrophobicity balance, internalisation ability, and/or the aggregation behaviour in biological media are likely hypotheses.

Finally, the possible detection of cancer cells by two-photon fluorescence imaging was investigated after incubation of the same cells with $25 \mu \mathrm{g} \mathrm{mL}^{-1}$ of porphyrins for $24 \mathrm{~h}$. All these PSs are highly internalised and prove highly luminescent upon excitation at $790 \mathrm{~nm}$ (Fig. 3 and ESI, Fig. S11). In line with its larger 2PA cross-section, compound 2b is much brighter than the others upon two-photon excitation. More unexpected is the fact that this compound outperforms 2c, whereas both compounds have the same two-photon brightness $\left(\Phi_{\mathrm{F}} \sigma_{2}\right)$. Again, other parameters than pure photophysical ones seem to be at the origin in this phenomenon. 


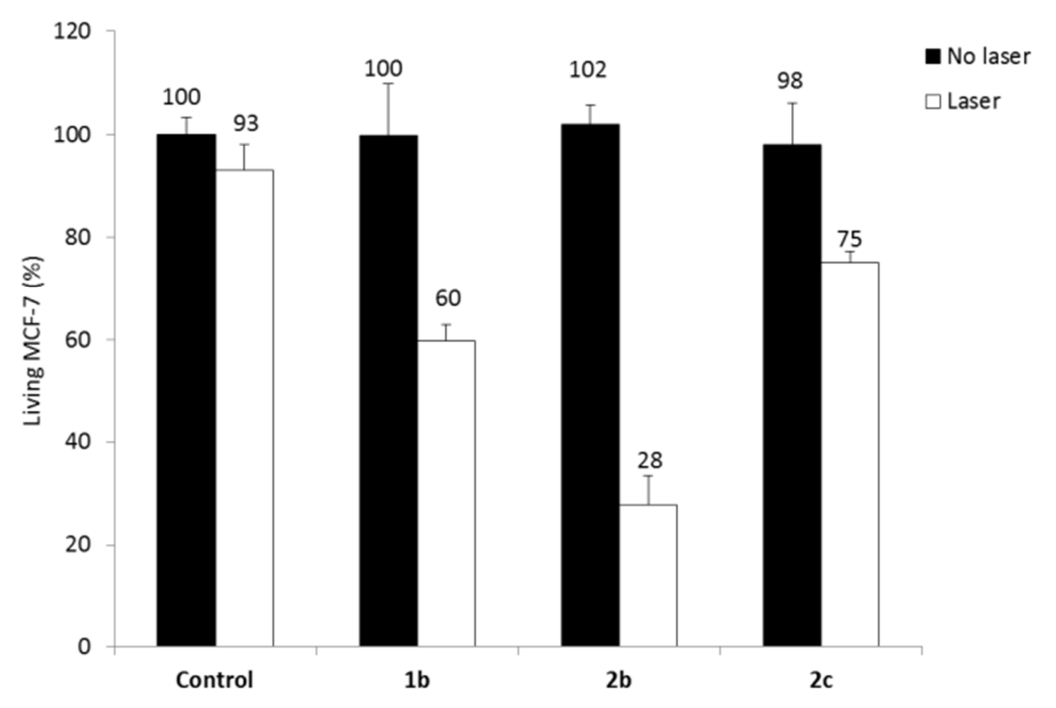

Fig. 2 2P-PDT efficacy of porphyrins on human breast cancer cells (MCF-7) after $24 \mathrm{~h}$ incubation with $\mathbf{1 b}$ and $\mathbf{2 b - c}$ at a concentration of $25 \mu \mathrm{g} \mathrm{mL} \mathrm{m}^{-1}$ during $24 \mathrm{~h}$ and irradiated with a focused laser $(10 \times / 0.3)$ at $790 \mathrm{~nm}$ by 3 pulses of $1.57 \mathrm{~s}$ each $\left(900 \mathrm{~mW} \mathrm{~cm}{ }^{-2}\right.$ output before the objective). Values are the mean of three experiments and error bars represent standard deviation.
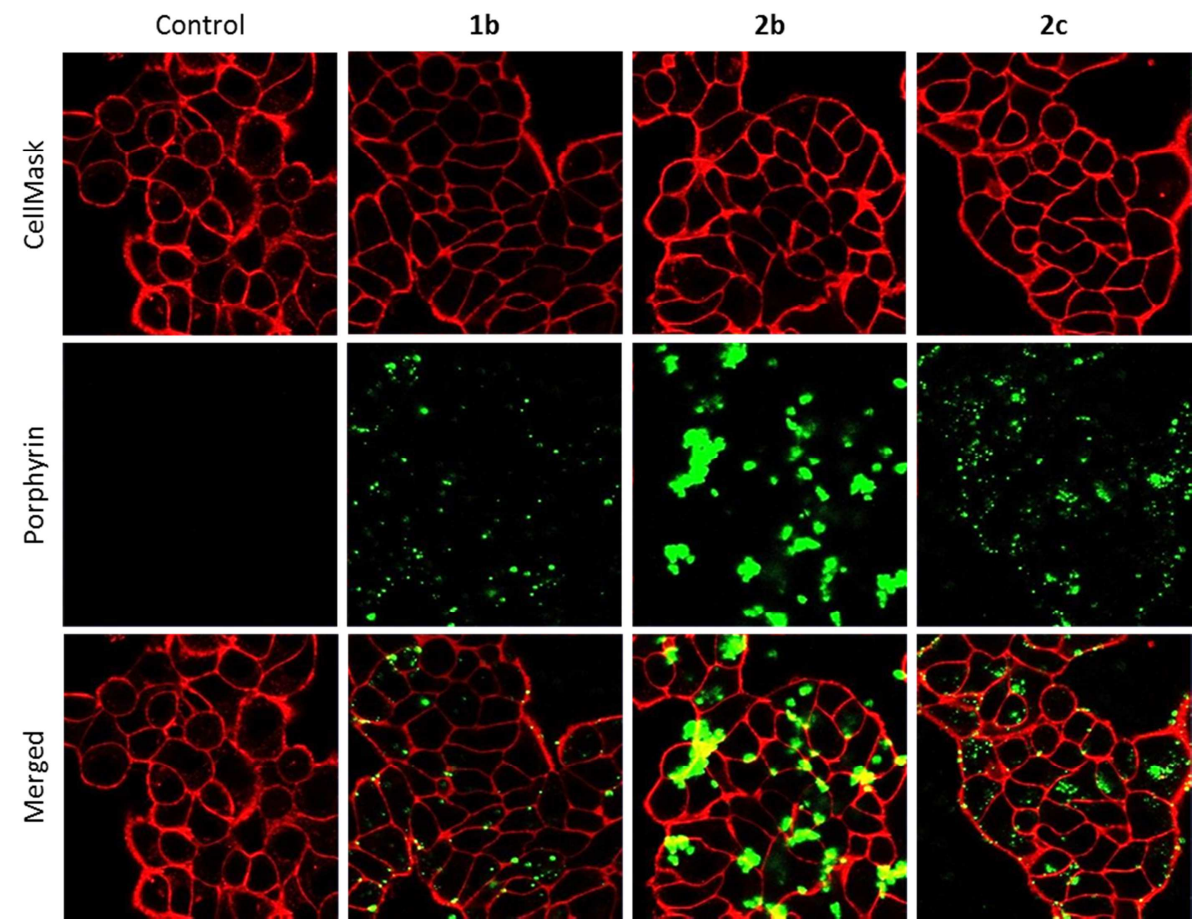

Fig. 3 Cancer cell uptake of porphyrins. Human breast cancer cells (MCF-7) were incubated for $24 \mathrm{~h}$ with porphyrins at a concentration of $25 \mu \mathrm{g} \mathrm{mL}^{-1}$. Membranes were stained with CellMask visualised in red under $\lambda_{\text {exc }}=561 \mathrm{~nm}$. Porphyrins were excited with pulsed laser $\lambda_{\text {exc }}=790 \mathrm{~nm}$ and appeared in green. Fluorescence imaging was performed on living cells with LSM780 (Chameleon), magnification $63 \times$, laser power $1.5 \%$. 
In conclusion, the new fluorenyl porphyrins $\mathbf{1 b}$ and $\mathbf{2 b - c}$ bearing water-solubilising TEG chains exhibit comparable singlet oxygen quantum yields and 2PA cross-sections than their lipophilic analogues 1a and $\mathbf{2 a}$, and retain sufficient fluorescence in water for two-photon fluorescence imaging. Based on the figure of merit used for 2P-PDT, a 28-fold enhancement is found for porphyrin $\mathbf{1 b}$, whereas a remarkable 66-fold enhancement is found for both $\mathbf{2 b}$ and 2c relative to $\mathrm{H}_{2}$ TPP. This makes them promising PSs for theranostic applications. Accordingly, the first in vitro testing with MCF-7 breast cancer cells confirms these expectations: the compounds are biocompatible and non-toxic in the dark, and become lethal for the cells after brief two-photon laser irradiations in the near-IR. Furthermore, owing to their fluorescence, their distribution and their internalisation within cells can be monitored by (two-photon) fluorescence imaging. Thus, these compounds are promising for combined twophoton photodynamic therapy and imaging, demonstrating their theranostic potential, the compound $\mathbf{2 b}$ being the best candidate in this respect. This study also reveals that other factors than photophysical one (reflected by the classical figures of merit $\Phi_{\Delta} \sigma_{2}$ and $\Phi_{\mathrm{F}} \sigma_{2}$ ) need to be considered to understand their efficacy in vitro. Further work aimed at identifying these additional parameters is underway.

The authors acknowledge the China Scholarship Council (CSC) for Ph.D. funding (L.S.). This project was supported by the departmental committees CD35 and CD85 of the "Ligue contre le Cancer du Grand-Ouest". We also thank Guillaume Clermont (ISM) for his help with the two-photon and singlet oxygen measurements, and Thomas Vivès (ENSCR) for DLS measurements.

\section{Conflicts of interest}

There are no conflicts to declare.

\section{Notes and references}

1. (a) J. P. Celli, B. Q. Spring, I. Rizvi, C. L. Evans, K. S. Samkoe, S. Verma, B. W. Pogue and T. Hasan, Chem. Rev., 2010, 110, 2795; (b) J. F. Lovell, T. W. B. Liu, J. Chen and G. Zheng, Chem. Rev., 2010, 110, 2839.

2. B. W. Pedersen, T. Breitenbach, R. W. Redmond and P. R. Ogilby, Free Radical Res., 2010, 44, 1383.

3. (a) F. Bolze, S. Jenni, A. Sour and V. Heitz, Chem. Commun, 2017, 53, 12857; (b) Z. Sun, L.-P. Zhang, F. Wu and Y. Zhao, Adv. Funct. Mater., 2017, 27, 1704079.

4. (a) J. D. Bhawalkar, N. D. Kumar, C. F. Zhao and P. N. Prasad, Lasers Surg. Med., 1997, 15, 201; (b) J. R. Starkey, A. K. Rebane, M. A. Drobizhev, F. Meng, A. Gong, A. Elliott, K. McInnerney and C. W. Spangler, Clin. Cancer Res. , 2008, 14, 6564; (c) H. A. Collins, M. Khurana, E. H. Moriyama, A. Mariampillai, E. Dahlstedt, M. Balaz, M. K. Kuimova, M. Drobizhev, V. X. D. Yang, D. Phillips, A. Rebane, B. C. Wilson and H. L. Anderson, Nat. Photon., 2008, 2, 420; (d) M. Gary-Bobo, Y. Mir, C. Rouxel, D. Brevet, I. Basile, M. 
Maynadier, O. Vaillant, O. Mongin, M. Blanchard-Desce, A. Morère, M. Garcia, J.-O. Durand and L. Raehm, Angew. Chem. Int. Ed., 2011, 50, 11425; (e) O. Vaillant, E. Cheikh Khaled, D. Warther, D. Brevet, M. Maynadier, E. Bouffard, F. Salgues, A. Jeanjean, P. Puche, C. Mazerolles, P. Maillard, O. Mongin, M. Blanchard-Desce, L. Raehm, X. Rébillard, J.-O. Durand, M. Gary-Bobo, A. Morère and M. Garcia, Angew. Chem. Int. Ed., 2015, 54, 5952; (f) J. Schmitt, V. Heitz, A. Sour, F. Bolze, P. Kessler, L. Flamigni, B. Ventura, S. Bonnet Célia and É. Tóth, Chem. Eur. J., 2016, 22, 2775; (g) C. Cepraga, S. Marotte, E. Ben Daoud, A. Favier, P.-H. Lanoë, C. Monnereau, P. Baldeck, C. Andraud, J. Marvel, M.-T. Charreyre and Y. Leverrier, Biomacromolecules, 2017, 18, 4022; (h) J. Schmitt, S. Jenni, A. Sour, V. Heitz, F. Bolze, A. Pallier, C. S. Bonnet, É. Tóth and B. Ventura, Bioconjugate Chem., 2018, 29, 3726; (i) A. Sourdon, M. Gary-Bobo, M. Maynadier, M. Garcia, J.-P. Majoral, A.-M. Caminade, O. Mongin and M. BlanchardDesce, Chem. Eur. J., 2019, 25, 3637.

5. (a) J. Schmitt, V. Heitz, A. Sour, F. Bolze, H. Ftouni, J.-F. Nicoud, L. Flamigni and B. Ventura, Angew. Chem. Int. Ed., 2015, 54, 169; (b) M. Zhu, J. Zhang, Y. Zhou, P. Xing, L. Gong, C. Su, D. Qi, H. Du, Y. Bian and J. Jiang, Inorg. Chem., 2018, 57, 11537; (c) M. Zhu, C. Su, P. Xing, Y. Zhou, L. Gong, J. Zhang, H. Du, Y. Bian and J. Jiang, Inorg. Chem. Front., 2018, 5, 3061.

6. M. Khurana, H. A. Collins, A. Karotki, H. L. Anderson, D. T. Cramb and B. C. Wilson, Photochem. Photobiol., 2007, 83, 1441.

7. (a) K. Ogawa, A. Ohashi, Y. Kobuke, K. Kamada and K. Ohta, J. Am. Chem. Soc., 2003, 125, 13356; (b) M. Drobizhev, Y. Stepanenko, Y. Dzenis, A. Karotki, A. Rebane, P. N. Taylor and H. L. Anderson, J. Am. Chem. Soc., 2004, 126, 15352; (c) H. Rath, J. Sankar, V. PrabhuRaja, T. K. Chandrashekar, A. Nag and D. Goswami, J. Am. Chem. Soc., 2005, 127, 11608; (d) D. Y. Kim, T. K. Ahn, J. H. Kwon, D. Kim, T. Ikeue, N. Aratani, A. Osuka, M. Shigeiwa and S. Maeda, J. Phys. Chem. A, 2005, 109, 2996; (e) F. Hammerer, S. Achelle, P. Baldeck, P. Maillard and M.-P. Teulade-Fichou, J. Phys. Chem. A, 2011, 115, 6503; (f) M. Pawlicki, M. Morisue, N. K. S. Davis, D. G. McLean, J. E. Haley, E. Beuerman, M. Drobizhev, A. Rebane, A. L. Thompson, S. I. Pascu, G. Accorsi, N. Armaroli and H. L. Anderson, Chem. Sci., 2012, 3, 1541; (g) A. Mikhaylov, D. V. Kondratuk, A. Cnossen, H. L. Anderson, M. Drobizhev and A. Rebane, J. Phys. Chem. C, 2016, 120, 11663; (h) L. M. Mazur, T. Roland, S. Leroy-Lhez, V. Sol, M. Samoc, I. D. W. Samuel and K. Matczyszyn, J. Phys. Chem. B., 2019, 123, 4271.

8. (a) W. R. Dichtel, J. M. Serin, C. Edder, J. M. J. Fréchet, M. Matuszewski, L.-S. Tan, T. Y. Ohulchanskyy and P. N. Prasad, J. Am. Chem. Soc., 2004, 126, 5380; (b) R. P. Brinas, T. Troxler, R. M. Hochstrasser and S. A. Vinogradov, J. Am. Chem. Soc., 2005, 127, 11851; (c) J.-B. Verlhac, G. Clermont and M. Blanchard-Desce, J. Porphyrins Phthalocyanines, 2017, 21, 77.

9. (a) Y. Wan, K. Jia, B. Li, Z. Bo and A. Xia, Sci. China, Ser. B: Chem., 2009, 52, 56; (b) O. Mongin, V. Hugues, M. Blanchard-Desce, A. Merhi, S. Drouet, D. Yao and C. PaulRoth, Chem. Phys. Lett., 2015, 625, 151; (c) D. Yao, V. Hugues, M. Blanchard-Desce, O. Mongin, C. O. Paul-Roth and F. Paul, New J. Chem., 2015, 39, 7730; (d) D. Yao, X. Zhang, O. Mongin, F. Paul and C. O. Paul-Roth, Chem. Eur. J., 2016, 22, 5583; (e) D. Yao, X. Zhang, A. Triadon, N. Richy, O. Mongin, M. Blanchard-Desce, F. Paul and C. O. Paul-Roth, Chem. Eur. J., 2017, 23, 2635; (f) D. Yao, X. Zhang, S. Abid, L. Shi, M. Blanchard-Desce, O. Mongin, F. Paul and C. O. Paul-Roth, New J. Chem., 2018, 42, 395; (g) X. Zhang, S. Abid, L. Shi, Z. Sun, O. Mongin, M. Blanchard-Desce, F. Paul and C. O. Paul-Roth, Dyes Pigm., 2018, 153, 248.

10. N. S. Makarov, M. Drobizhev and A. Rebane, Opt. Express, 2008, 16, 4029. 


\section{Graphic Content Entry}

Three new biocompatible porphyrin-based oxygen photosensitisers were tested in vitro on breast cancer cells via 2P-PDT: one of them, 66 times more active than $\mathrm{H}_{2} \mathrm{TPP}$, gave quite promising results for theranostic applications.

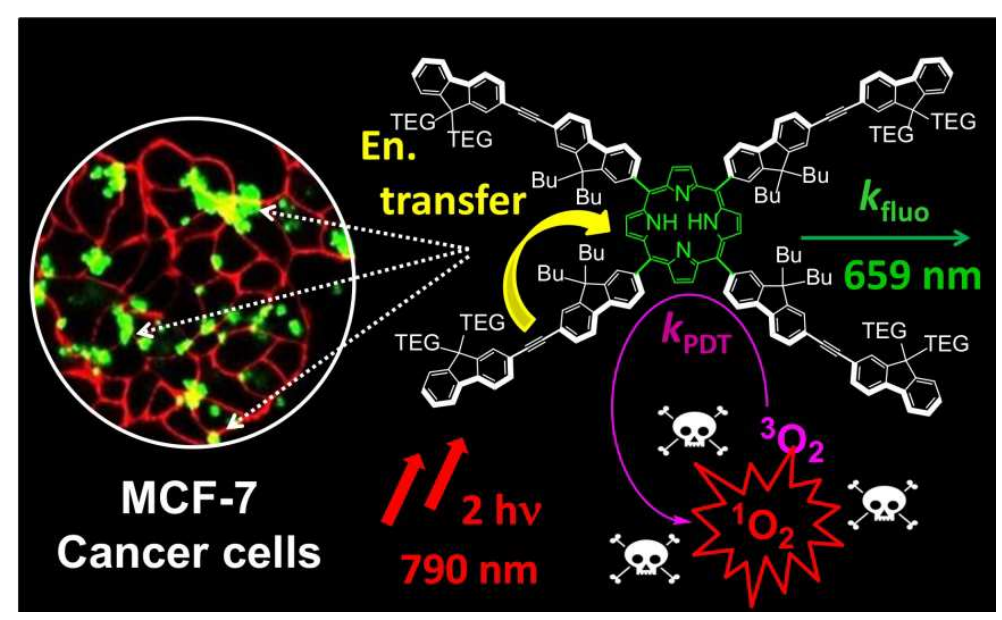

